\title{
A Case of Congenital Factor VII Deficiency Presented with Subacute Subdural Hematoma
}

\author{
Min Kyoung Kim, Sang Jun Shin, Kyung Ok Kim, \\ Kyung Hee Lee, Myung Soo Hyun, Hee Soon Cho* \\ Department of Internal Medicine, \\ *Department of Laboratory Medicine, \\ College of Medicine, Yeungnam University, Daegu, Korea
}

\section{-Abstract-}

A congenital factor VII deficiency is a rare disorder with an estimated incidence in the western contries of one in 500,000. Because factor VII is important in initiation the coagulation cascade, a factor VII deficiency can result in significant bleeding with prolongation of the prothrombin time. We present a case of a factor VII deficiency with a subdural hematoma in an 18-year-old boy whose plasma activity of factor VII was $\leq 10 \%$. Previously, he did not have any symptoms, such as hemarthrosis, easy bruising or bleeding after a minor trauma. He was administered fresh frozen plasma and a trephination was performed. His sister also had $51 \%$ lower level of factor VII.

Key Words: Factor VII deficiency, Prothrombin time

\section{Introduction}

A congenital factor VII deficiency is a rare disorder, which was first described by Alexander et al. in 1951. ${ }^{1)}$ It is transmitted as an autosomal recessive trait and the heterozygous state is usually asymptomatic where as the homozygous condition is variably symptomatic.2)

Most patients experience a mild bleeding disorder that is characterized by mucosal bleeding, epistaxis and menorrhagia. Occasionally a more severe episode of bleeding can occur. 
- Min Kyoung Kim, Sang Jun Shin, Kyung Ok Kim, Kyung Hee Lee, Myung Soo Hyun, Hee Soon Cho-

A factor VII deficiency is a hereditary clotting factor deficiency, which causes an isolated prolongation of the prothrombin time in the presence of a normal activated partial thromboplastin time. A specific factor VII assay is needed to confirm the diagnosis.

The incidence in western contries is estimated to be one in 500,000 ${ }^{3)}$ and the first case in Korea was reported in 1983. ${ }^{4)}$ Since then, a few cases of a congenital factor VII deficiency have been reported. ${ }^{5-8)}$

Recently we experienced a case of a factor VII deficiency that presented with a subacute subdural hematoma and managed with the administration of fresh frozen plasma and trephination.

\section{Case report}

An 18-yr-old male patient was admitted to the department of neurosurgery complaining of severe headache and vomiting for several days. He had participated in a self-denial program at his high school 30 days ago. He had no specific medical problem previously and his family history was nonspecific.

His blood pressure was 120/75 mmHg, pulse rate $65 / \mathrm{min}$, respiratory rate $16 / \mathrm{min}$, and body temperature $36.5^{\circ} \mathrm{C}$. A physical examination revealed no specific abnormal findings.

His skin was unremarkable. No cervical, axillary, and inguinal lymphadenopathy were noted. The results of the lung and heart examinations were within the normal limits. His abdomen was soft without splenomegaly. The results of the neurologic examination were also within the normal limits.

The initial laboratory findings were as follows. For the blood chemistry, the white blood cell count was $6 \times 10^{9} / \mathrm{L}$ (segment neutrophil 52\%, lymphocyte 35\%), hemoglobin $13.8 \mathrm{~g} / \mathrm{dL}$ and platelet count $253 \times 10^{9} / \mathrm{L}$ on complete blood cell count (CBC), blood urea nitrogen $14 \mathrm{mg} / \mathrm{dL}$, creatinine $0.8 \mathrm{mg} / \mathrm{dL}$, protein $7.9 \mathrm{~g} / \mathrm{dL}$, albumin $4.5 \mathrm{~g} / \mathrm{dL}$, fasting blood glucose $80 \mathrm{mg} / \mathrm{dL}$, aspartate aminotransferase $20 \mathrm{IU} / \mathrm{L}$, alanine aminotransferase 9 IU/L and alkaline phosphatase 142 IU/L. The urine and stool occult blood test were negative. An abnormal result was found in the coagulation test. His bleeding time was 1 min, within the normal range but the prothrombin time was severely prolonged (36.5 sec, 22\%, INR 3.98) and the activated partial thromboplastin time was normal (34.9 $\mathrm{sec})$. After mixing the normal and pathological plasma, the prothrombin time of patient was corrected (13.4 sec) and there was no response after administering the vitamin $\mathrm{K}$. The factor assay revealed that the factor VII level was $\leq 10$ percent of the normal activity but the factor IX and X levels were within the normal limits (105\% and 88\% respectively).

The magnetic resonance imaging (MRI) of the brain was performed in order to rule out a brain lesion because of his symptom, 


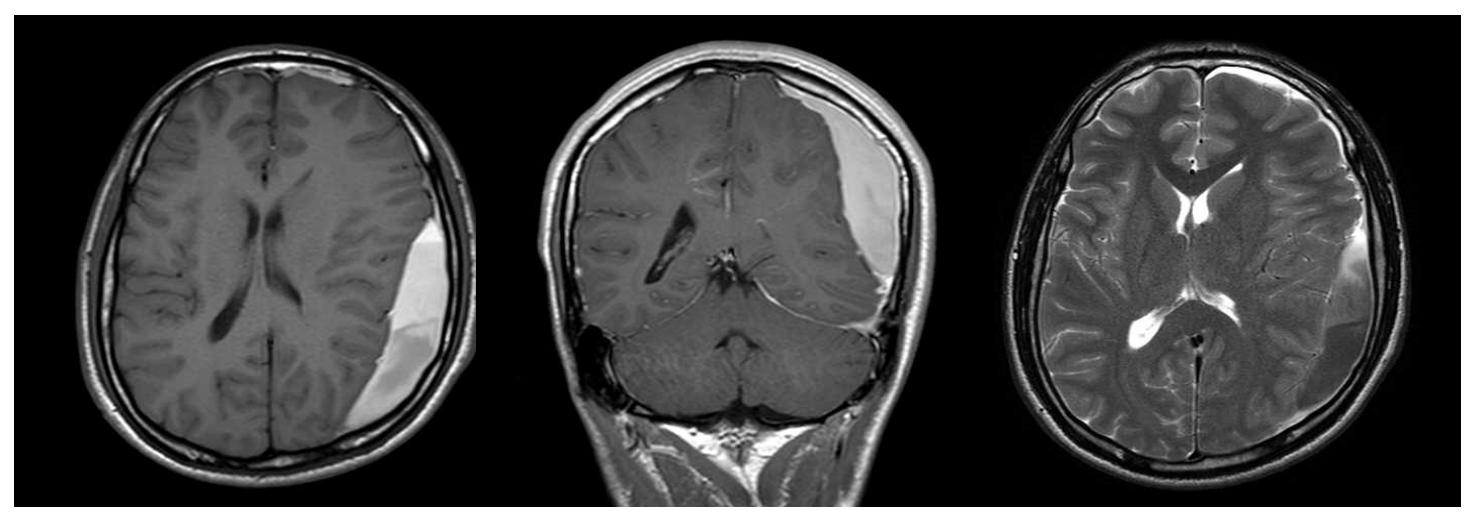

Fig. 1. Brain MRI shows subdural hematoma in left temporo-occipital area with compression of lateral ventricle (T1WI axial, coronal (enhanced) \& T2WI axial view).

headache and vomiting. The MRI of brain liver.

revealed a subdural hematoma in the left The first reported case of a factor VII temporo-occipital area with a compression of deficiency was first described by Alexander the lateral ventricle (Fig. 1).

et al. in $1951^{1)}$ under the name serum

The patient was diagnosed with a subacute subdural hematoma with a factor VII deficiency. In preparation for surgery he received a dose of $15 \mathrm{ml} / \mathrm{Kg}$ of fresh frozen plasma and the dose was repeated every 12 hours for 2 days. Trephination was performed. After surgery, no bleeding signs were noted. The hematoma was drained well and the patient's symptom improved.

Among his family his sister also had a subclinical factor VII deficiency with a factor VII was of $51 \%$.

\section{Discussion}

Factor VII is a vitamin $\mathrm{K}$-dependent, 50,000-dalton molecular weight glycosylated plasma protein that is synthesized by the prothrombin conversion accelerator deficiency. Also known as a stable factor or a proconvertin deficiency, the condition is inherited as an autosomal recessive trait and affects males and females equally. ${ }^{2)}$ The gene for factor VII includes nine exons and spans $128 \mathrm{~kb}$ on chromosome $13^{9)}$ It is located immediately upstream of the factor $\mathrm{X}$ gene. More than 115 mutations were listed in 2002 in a registry maintained by the Medical Research Council. ${ }^{10)}$ The molecular basis for an inherited factor VII deficiency has been determined for a number of individuals, resulting in the identification of a variety of nonsense, missense, and splicesite mutations throughout the factor VII coding region, as well as a few small deletions and at least one mutation in the 
- Min Kyoung Kim, Sang Jun Shin, Kyung Ok Kim, Kyung Hee Lee, Myung Soo Hyun, Hee Soon Cho-

promoter region which cause reduced factor VII levels. ${ }^{11)}$

Individuals with a severe deficiency can suffer clinical hemorrhage as serious as those with severe classical hemophilia even thogh the correlation between the factor VII levels and the bleeding tendency is not particularly strong. One series cites a 16\% incidence of intracranial bleeding in 75 patients with a factor VII deficiency. ${ }^{12)} \mathrm{A}$ CNS hemorrhage often presents during the neonatal period and the risk of a recurrence is high, Therefore, a prophylaxis with factor replacement therapy should be considered in patients who present with this complication. ${ }^{13)}$ In our case, the patient suffered a subdural hematoma after a minor trauma after participating in a self-denial program. However, he had no prior abnormal bleeding episodes. He was suspected of having some disorders in hemostasis and coagulation, and he had an isolated prolongation of the prothrombin time. At factor assay showed that he had factor VII deficiency only.

Liver disease, warfarin, propylthiouracil or salicylate ingestion, or a vitamin $\mathrm{K}$ deficiency might mimic a factor VII deficiency but these disorders may be distinguished by measuring the other vitamin $\mathrm{K}$ dependent factors or the repeat factor VII level assay after a vitamin $\mathrm{K}$ injection. In addition, rare conditions, such as a combined factor VII and factor $\mathrm{X}$ deficiency should be considered. In our patient, the factor IX and $\mathrm{X}$ levels were within the normal limits. Although Dubin-Johnson syndrome is associated with a factor VII deficiency, the genetic defect underlying that syndrome is located on chromosome 10, and a factor VII deficiency might simply reflect the high consanguinity rate in one population. ${ }^{1)}$ Our patient showed no laboratory and clinical evidence of DubinJohnson syndrome.

Although the necessity for correcting a factor VII deficiency is controversial, patients who have a factor VII deficiency and a history of excessive clinical bleeding should be given replacement therapy prior to surgery. A factor VII deficiency with clinical bleeding can be treated with fresh frozen plasma, a prothrombin complex concentrate or a purified factor VII concentrate. In our case, neither the prothrombin complex concentrate nor the purified factor VII concentrate was available, so fresh frozen plasma was used for the hemostasis instead. For a spontaneous hemorrhage or mild trauma, therapeutic factor VII levels of approximately 5 10\% are sufficient to stop bleeding. ${ }^{1)}$ This can be achieved by administering plasma at a dose of $5 \sim 10 \mathrm{ml} / \mathrm{Kg}$ and repeating the dose every $8 \sim 12$ hours for 1 2 days. For a major hemorrhage or surgery, a loading dose of $15 \sim 20 \mathrm{ml} / \mathrm{kg}$ and repeating the dose for $5 \sim 7$ days is required. ${ }^{14)}$

Our patient had a trephination after the transfusion of fresh frozen plasma and his hematoma was resolved. 
In summary, we encountered a case of a congenital factor VII deficiency with subacute subdural hematoma that occurred spontaneously or after a minor trauma. Although a congenital factor VII deficiency is very rare, a congenital factor VII deficiency should be considered in cases of unusual major bleeding combined with an isolated prolongation of the prothrombin time.

\section{요 약}

제 VII 혈액응고인자는 외인계 혈액응고기전 에 매우 중요한 역할을 한다. 선천성 제 VII 혈 액응고인자 결핍증은 구미에서는 인구 500,000 명당 한명의 발생률을 보이는 드문 질환으로 상염색체 열성으로 유전되는 것으로 알려져 있 으며 국내에서의 보고는 드물다.

이에 저자들은 경막하 출혈로 입원한 환자 에서 발견된 선천성 제 VII 혈액응고인자 결핍 증을 경험하고 보고하는 바이다.

\section{Reference}

1. Alexander B, Goldstein R, Landwehr G, Cook CD. Congenital SPCA deficiency : a hitherto unrecognized coagulation defect with hemorrhage rectified by serum and serum fractions. J Clin Invest 1951 Jun;30(6):596-608.

2. Cleton FJ, Leoliger EA. Two typical hereditary charts of congenital factor VII deficiency. Thromb Diath Haemorr 1960 Oct 1;5:87-92.

3. Marder VJ, Shulman NR. Clinical aspects of congenital factor VII deficiency. Am J Med 1964 Aug;37:182-94.
4. Park JY, Shin HY, An HS, Cho HI. A case of congenital factor VII deficiency. Korean J Hematol 1983 18:109-12.

5. Doh YJ, Kim MH, Nahm CH, Song KS, Kwon $\mathrm{OH}$. Four cases report of congenital factor VII deficiency. Korean J Hematol 1992 27:435-41.

6. Lee HW, Kim EY, Choi SS, Yoon HR, Kim JJ, Pai SH. Two cases of congenital factor VII deficiency with family study. Korean J Hematol 1997 32:423-7.

7. Kwon HJ, Moon HS. A cases of factor VII deficiency with normal factor VII antigen level. Korean J Hematol 1997 32:419-22.

8. Oh HM, Whang HC, Lim SJ, Kim JH, Kim YK, Kim SY, Kim YJ, Cho MK, Lee GJ. A case of hereditary factor VII deficiency performed operation without any replacement therapy. Korean J Hematol 2001 36:351-4.

9. O’Hara PJ, Grant FJ, Haldeman BA, Gray CL, Insley MY, Hagen FS, Murray MJ. Nucleoside sequence of the gene coding for human factor VII, a vitamin $\mathrm{K}$-dependent protein participating in blood coagulation. Proc Natl Acad Sci USA 1987 Aug;84(15):5158-62.

10. Friedman KD, Rodgers GM. Inherited coagulation disorder. In: Greer JP, Foerster J, Lukens JN, Rodgers GM, Paraskevas F, Glader B. Wintrobe's clinical hematology, 11th ed. Lippincott Williams \& Wilkins; 2003. p.1620-67.

11. James HM. Tissue factor and factor VII initiation of coagulation. In: Colman RW, Hirsh J, Marder VJ, Clowes AW, George JN. Hemostasis and thrombosis:basic principles and clinical practice. 4th ed. Philadelphia: Lippincott Williams \& Wilkins; 2001. p.89-101.

12. Ragni MV, Lewis JH, Spero JA, Hasiba U. Factor VII deficiency. Am J Hematol 1981; 10(1):79-88.

13. Cohen LJ, McWilliams NB, Neuberg R. Zinkham W, Bauer K, Gribble TJ, Glowalla 
- Min Kyoung Kim, Sang Jun Shin, Kyung Ok Kim, Kyung Hee Lee, Myung Soo Hyun, Hee Soon Cho-

$\mathrm{MB}$ et al. Prophylaxis and therapy with factor

VII concentrate(human) Immuno, vapor heated in patients with congenital factor VII deficiency : a summary of case reports. Am J Hematol 1995 Dec;50(4):269-76.

14. Roberts HR, Hoffman M. Other clotting factor deficiencies. In: Hoffman R, Benz EJ Jr, Shattil SJ, Furie B, Cohen HJ, Silberstein LE, McGlave P. Hematology: basic principles \& practice. 3rd ed. Churchill Livingstone: 2000. p.1912-24. 